\title{
ANALISA PERUBAHAN PENGGUNAAN LAHAN TERHADAP POTENSI BANJIR DI KECAMATAN MEDAN DENAI
}

\author{
Wirawan Masyhuri \\ Jurusan Pendidikan Geografi, Fakultas IImu Sosial, Universitas Negeri Medan \\ Jl. Willem Iskandar Pasar V Medan, 20221, Indonesia \\ E-mail:wirazaz@gmail.com
}

\begin{abstract}
Abstrak
Penelitian ini bertujuan untuk: (1) mengidentifikasi pola perubahan penggunaan lahan di Kecamatan Medan Denai pada tahun 2008 - 2013, (2) mengetahui pola perubahan penggunaan lahan di Kecamatan Medan Denai yang menunjukkan potensi banjir. Penelitian ini dilakukan di Kecamatan Medan Denai Kota Medan tahun 2014. Populasi penelitian ini adalah penggunaan lahan di Kecamatan Medan Denai pada tahun 2008 dan 2013. Sampel penelitian ini ditentukan secara acak atau menggunakan teknik random sampling yakni berupa penggunaan lahan yang dominan di Kecamatan Medan Denai , yaitu permukiman/lahan terbangun, lahan terbuka, lahan jasa, kebun campuran, lahan pertanian. Teknik pengumpulan data yang digunakan adalah studi dokumentasi, interpretasi, kerja lapangan dan analisis. Teknik analisis data yang dilakukan yaitu analisis deskriptif kualitatif. Hasil dari penelitian ini adalah : (1) penggunaan lahan yang paling banyak mengalami penambahan luas dalam kurun waktu 5 tahun terakhir adalah permukiman/lahan terbangun sebesar $96,55 \%$, dan penggunaan lahan yang paling sedikit mengalami penambahan luas adalah lahan jasa sebesar 3,45\%. Sedangkan kebun campuran mengalami penurunan luas sebesar 59,94\%, lahan sawah sebesar 5,23\%, lahan terbuka sebesar 30,83\%, dan lahan tegalan sebesar 4,01\% dari total luas lahan yang berubah. (2) penggunaan lahan yang di Kecamatan Medan Denai yang mengakibatkan banjir muncul akibat dominasi lahan permukiman/ lahan terbangun dengan jumlah titik yang bertambah dari 9 titik pada tahun 2008 berubah menjadi 16 titik pada tahun 2013 serta luasan yang bertambah. Kelurahan Tegal Sari Mandala 3 merupakan yang rentan terkena banjir karena lahan permukiman/ lahan terbangun yang padat cukup mendominasi, jumlah titik genangan/ banjir yang tadinya hanya 3 titik berubah menjadi 4 titik dengan luasan yang bertambah.
\end{abstract}

Kata kunci: penggunaan lahan, banjir

\section{PENDAHULUAN}

Penggunaan lahan berhubungan erat dengan aktivitas manusia dan sumberdaya lahan (Sitorus, 2011). Pertumbuhan dan perkembangan kota dipengaruhi oleh adanya berbagai faktor, antara lain faktor kependudukan, serta adanya interaksi antara kota dengan kota lainnya dalam lingkup wilayah maupun luar wilayah suatu daerah. Perkembangan faktor tersebut (penduduk, kegiatan penduduk dan interaksi kota dengan wilayah lain) merupakan pemicu tumbuh dan berkembangnya wilayah yang berdampak terhadap terjadinya perubahan fisik dan penggunaan lahan. Bentuk perubahan penggunaan lahan ditandai dengan makin meningkatnya lahan terbangun, yang merupakan fenomena perkembangan dan pertumbuhan wilayah perkotaan yang mudah terlihat secara fisik (Samosir, 2011).

Perubahan penggunaan lahan yang terjadi tanpa dilakukannya perencanaan dan pengendalian maka akan menimbulkan kerusakan lingkungan. Sebagai contoh adalah penggunaan lahan hutan menjadi areal pertanian dan perkebunan yang masih belum mempertimbangkan konsep konservasi lahan. Hal ini mengakibatkan penggunaan lahan menjadi kurang optimal 
ditinjau dari sisi lingkungan yang akan memberikan kontribusi dalam memperparah bencana kerusakan lahan. Dengan aktivitas dan kepentingan manusia yang berbeda-beda merupakan hal mendasar terjadinya perubahan suatu penggunaan lahan. Jumlah lahan yang terbatas menyebabkan alih fungsi lahan dari lahan kosong atau lahan terbuka menjadi lahan permukiman untuk memenuhi kebutuhan penduduk yang terus meningkat.

Perkembangan dan pembangunan daerah yang dilakukan pemerintah dalam menyediakan infrastruktur dan pelayanan dapat berimplikasi terhadap peningkatan kebutuhan lahan. Semakin pesatnya pembangunan yang dilakukan menimbulkan keterbatasan dan kebutuhan lahan yang meningkat didukung oleh bertambahnya jumlah penduduk, kegiatan sosial, kegiatan ekonomi berdampak semakin meningkatnya perubahan penggunaan lahan di wilayah tersebut.

Seiring dengan meningkatnya kebutuhan lahan tersebut dalam rangka pembangunan daerah maupun untuk memenuhi kebutuhan penduduk secara tidak langsung mengurangi daerah resapan air yang juga berkontribusi atas meningkatnya debit banjir. Pada daerah permukiman yang padat dengan bangunan tingkat resapan air ke dalam tanah berkurang, jika terjadi hujan dengan curah hujan yang tinggi sebagian besar air akan menjadi aliran air permukaan yang langsung masuk ke dalam sistem pengaliran air, sehingga kapasitasnya terlampaui dan mengakibatkan banjir (Anonim, 2007). Penelitian Damanik dan Restu (2012) mengemukakan bahwa sebagian wilayah Kota Medan tergolong pada wilayah dengan tingkat kerentanan banjir mulai dari sedang hingga sangat tinggi. Bahkan dikatakan bahwa, sebagian besar Kota Medan tergolong pada tingkat kerentanan sangat tinggi.

Dalam hal ini perkembangan fisik kota yang cukup pesat juga terjadi di Kota Medan. Perkembangan fisik ini menyebabkan terjadinya pergeseran struktur dan pola pemanfaatan ruang, sehingga perlu dilakukan penyesuaian dengan kecenderungan perubahan kondisi yang terjadi. Peran Kota Medan sebagai pusat pengembangan utama di wilayah daratan serta menjadi pusat pertumbuhan utama di Provinsi Sumatera Utara menjadikan Kota Medan wilayah yang strategis bagi pengembangan wilayah kota. Selain itu sebagai pusat administrasi Provinsi Sumatera Utara, Kota Medan menjadi pusat ekonomi, pemerintahan, pendidikan dan sosial budaya yang mengakibatkan semakin meningkatnya jumlah penduduk di Kota Medan baik dari penduduk asli maupun pendatang dari daerah lain.

Kecamatan Medan Denai merupakan salah satu dari 21 kecamatan di Kota Medan yang ikut serta menyokong kemajuan pembangunan mempunyai cakupan wilayah administratif seluas 9,91 $\mathrm{km}^{2}$ dengan jumlah penduduk 142.001 jiwa yang tersebar di enam kelurahan, dengan tingkat kepadatan penduduk mencapai $29.333 \mathrm{jiwa} / \mathrm{km}^{2}$ (BPS Kota Medan, 2013). Kepadatan penduduk yang disebabkan oleh urbanisasi membuat lahan sebagai daerah resapan di Kecamatan Medan Denai semakin berkurang sehingga pelaksanaan pembangunan yang sudah direncanakan sebelumnya tidak berjalan dengan optimal.

Kecamatan Medan Denai memiliki daerah permukiman dengan kepadatan cukup tinggi dan juga termasuk dalam daftar kawasan rawan banjir, tercantum dalam Rencana Tata Ruang Wilayah Kota Medan Tahun 2011-2031. Dengan demikian dalam orientasi pengembangan wilayah Kota Medan, Kecamatan Medan Denai pada masa-masa mendatang dipastikan akan semakin tumbuh dan berkembang secara pesat (BPS Kota Medan, 2013).

Pembangunan permukiman yang cukup pesat di Kecamatan Medan Denai merupakan implikasi dari posisi Kecamatan Medan Denai sebagai wilayah yang berada di tepi kota inti (Medan). Dengan membesarnya ukuran kota inti dan berkembangnya pusat - pusat permukiman, maka meningkat pula interaksi di antara keduanya. Interaksi tersebut tercermin dari meningkatnya pergerakan penduduk yang melalui Kecamatan Medan Denai. Pembesaran ukuran kota inti juga menyebabkan peningkatan permintaan lahan bagi kegiatan ekonomi dan permukiman. Peningkatan tersebut ditandai dengan peningkatan harga lahan secara signifikan. Secara keseluruhan hal ini menyebabkan perkembangan fisik yang pesat di Kecamatan Medan Denai. Hal ini menyebabkan perubahan penggunaan 
lahan kebanyakan dari lahan terbuka menjadi lahan permukiman.

Dampak dari pembangunan permukiman yang cukup pesat tersebut menunjukkan efek yang buruk dengan sejumlah jalan utama di Kecamatan Medan Denai terendam air usai hujan lebat mengguyur Kota Medan. Bahkan tepat pada tanggal 15 Oktober 2013 lalu, ribuan rumah di Kota Medan digenangi banjir diantaranya Kecamatan Medan Denai yang juga ikut terkena imbas dengan ketinggian selutut orang dewasa (Karoko, 2013.

Teknologi penginderaan jauh merupakan salah satu cara untuk mengetahui secara cepat alih fungsi lahan. Penggunaan teknologi penginderaan jauh secara temporal dapat digunakan untuk mengetahui dinamika proses dan memprediksi perubahan penutupan dan penggunaan lahan di masa yang akan datang yaitu melalui monitoring dan karakterisasi pola spasial penutupan dan penggunaan lahan. Teknik analisisnya secara efisien dapat menggunakan data penginderaan jauh dan Sistem Informasi Geografis (SIG) (Petit et al. 2001, Prahasta, 2009). Lebih lanjut Irianto (2004) menyatakan bahwa penggunaan citra satelit dengan resolusi dan waktu pengambilan yang proporsional multitemporal sangat diperlukan untuk zonasi, karakterisasi, adaptasi dan mitigasi alih fungsi lahan. Sementara itu, model perubahan penggunaan lahan dapat digunakan sebagai alat untuk memahami dan menjelaskan penyebab dan frekuensi dari dinamika penggunaan lahan. Berdasarkan hal tersebut, peneliti menggunakan citra satelit multitemporal, yaitu citra satelit Quickbird tahun 2008 dan 2013. Citra digital ini memiliki resolusi spasial 0,61 m - 2,4 m dan merupakan sumber yang sangat baik dalam pemanfaatannya untuk studi lingkungan dan analisis perubahan penggunaan lahan, pertanian, dan kehutanan. Maka penelitian ini mencoba menganalisis dan mengidentifikasi perubahan penggunaan lahan di Kecamatan Medan Denai , Kota Medan yang terjadi antara tahun 2008 sampai dengan tahun 2013 dengan menggunakan bantuan teknologi penginderaan jauh.

\section{METODOLOGI PENELITIAN}

Penelitian ini berlokasi di Kota Medan tepatnya di Kecamatan Medan Denai . Alasan pemilihan lokasi dikarenakan jumlah penduduk yang setiap tahun mengalami peningkatan dan kebiasaan masyarakat serta kebijakan pemerintah yang kurang baik dalam menyikapi penggunaan lahan.

Populasi dalam penelitian ini adalah penggunaan lahan pada tahun 2008 dan 2013 di Kecamatan Medan Denai yang merupakan bagian dari wilayah administrasi Kota Medan dan terdiri dari Kelurahan/Desa Tegal Sari Mandala I, Kelurahan/Desa Tegal Sari Mandala II, Kelurahan/Desa Tegal Sari Mandala III, Kelurahan/Desa Denai, Kelurahan/Desa Binjai, Kelurahan/Desa Medan Tenggara. Dengan teknik random sampling, maka yang menjadi sampel penelitian ini adalah : penggunaan lahan yang mendominasi dalam pemanfaatan lahan seperti pemukiman, lahan terbuka, lahan pertanian, kebun campuran, dan lahan jasa.

Adapun yang menjadi variabel dalam penelitian ini adalah:

- Daerah Genangan

- Perubahan Penggunaan Lahan

- Penggunaan Lahan

- Lahan

- Lahan Terbuka

- Permukiman

- Lahan Jasa

- Lahan kebun campuran

- Lahan pertanian

Penelitian ini menggunakan teknik pengumpulan meliputi beberapa tahapan, yaitu sebagai berikut :

1. Studi Dokumentasi

- Data spasial (citra) dalam penelitian ini diperoleh dari Google Earth Version Pro 7.1.2.2041.

- Data - data dari instansi pemerintahan seperti data letak, luas, dan batas administrasi Kecamatan Medan Denai , kondisi fisik daerah, kondisi sosial ekonomi, bentuk dan fungsi penggunaan lahan Kecamatan Medan Denai , peta administrasi Kecamatan Medan Denai, dsb.

2. Interpretasi

Kegiatan interpretasi adalah kegiatan mengolah data yang ada sehingga menghasilkan informasi yang baru. Kegiatan ini dilakukan di komputer, yang 
berupa interpretasi visual dan digital, dengan cara menginterpretasi citra untuk memisahkan objek - objek tertentu sehingga dapat menghasilkan peta. Output dari kegiatan ini adalah peta tentatif yang selanjutnya akan diuji keakuratannya.

3. Kerja Lapangan

Kerja lapangan dilakukan setelah mendapatkan data dari tahap interpretasi. Kerja lapangan meliputi kegiatan uji ketelitian dan observasi.

\section{Analisis}

Analisis pada tahap ini adalah kegiatan reinterpretasi (menginterpretasi ulang) peta setelah melakukan kerja lapangan. Dari proses reinterpretasi maka akan dihasilkan peta perubahan penggunaan lahan yang telah di-overlay (data tahun 2008 dan 2013).

Teknik analisis data dalam penelitian ini menggunakan teknik deskriptif kualitatif. Teknik ini digunakan untuk mengetahui perubahan penggunaan lahan Kecamatan Medan Denai selama 5 tahun terakhir yaitu tahun 2008 hingga 2013 dan membandingkan dengan data - data sekunder yang diperoleh. Selanjutnya dari peta perubahan penggunaan lahan
Kecamatan Medan Denai tersebut juga banyak titik genangan banjir.

Data yang diperoleh atau yang dihasilkan akan diolah dan diklasifikasikan berdasarkan jumlah perubahan penggunaan lahan tiap wilayah sehingga berbentuk susunan urutan data dalam tabel atau diagram. Dalam tahap ini pengecekan ulang perlu dilakukan agar data yang diperoleh sama dengan informasi dan catatan yang diperoleh peneliti sebelumnya (Miles, 1992).

\section{HASIL DAN PEMBAHASAN}

Hasil dari penelitian ini adalah dapat dilihat bahwa penggunaan lahan yang paling banyak mengalami penambahan luas dalam kurun waktu 5 tahun terakhir adalah permukiman/lahan terbangun sebesar 96,55\%, dan penggunaan lahan yang paling sedikit mengalami penambahan luas adalah lahan jasa sebesar $3,45 \%$. Sedangkan kebun campuran mengalami penurunan luas sebesar $59,94 \%$, lahan sawah sebesar 5,23\%, lahan terbuka sebesar 30,83\%, dan lahan tegalan sebesar $4,01 \%$ dari total luas lahan yang berubah (Tabel 1).

Tabel 1. Luas Penggunaan Lahan di Kecamatan Medan Denai Tahun 2008 dan Tahun 2013

\begin{tabular}{|c|c|c|c|c|c|c|c|c|}
\hline & \multicolumn{2}{|c|}{ Tahun 2008} & \multicolumn{2}{|c|}{ Tahun 2013} & \multicolumn{2}{|c|}{ Perubahan } & \multicolumn{2}{|c|}{ Laju } \\
\hline Penggunaan Lahan & $\begin{array}{l}\text { Luas } \\
\text { (ha) }\end{array}$ & (\%) & $\begin{array}{l}\text { Luas } \\
\text { (ha) }\end{array}$ & (\%) & $\begin{array}{l}\text { Luas } \\
\text { (ha) }\end{array}$ & (\%) & $\begin{array}{l}\text { Luas } \\
\text { (ha) }\end{array}$ & (\%) \\
\hline Lahan Jasa & 0,86 & 0,09 & 2,66 & 0,28 & 1,80 & 3,45 & 0,36 & 13,56 \\
\hline Kebun Campuran & 92,03 & 9,81 & 60,74 & 6,47 & $-31,29$ & 59,94 & $-6,26$ & $-6,80$ \\
\hline $\begin{array}{l}\text { Permukiman/Lahan } \\
\text { Terbangun Lahan }\end{array}$ & 782,45 & 83,39 & 832,86 & 88,76 & 50,41 & 96,55 & 10,08 & 1,21 \\
\hline Sawah & 4,80 & 0,51 & 2,14 & 0,23 & $-2,73$ & $-5,23$ & $-0,55$ & $-11,38$ \\
\hline Lahan Terbuka & 37,41 & 3,99 & 21,31 & 2,27 & $-30,83$ & 43,04 & $-3,22$ & $-8,61$ \\
\hline Lahan Tegalan & 15,59 & 1,66 & 13,50 & 1,44 & $-4,01$ & $-13,41$ & $-0,42$ & 2,69 \\
\hline Tubuh Air & 5,13 & 0,55 & 5,13 & 0,55 & 0 & 0 & 0 & 0 \\
\hline Jumlah & 938,36 & 100 & 938,36 & 100 & & & & \\
\hline
\end{tabular}

Perubahan penggunaan lahan yang sangat tinggi di Kecamatan Medan Denai merupakan pemicu terjadinya banjir. Tingginya konversi lahan menjadi permukiman/lahan terbangun dalam kurun waktu 2008 hingga 2013 mengakibatkan bertambahnya titik banjir dari 9 titik pada tahun 2008 berubah menjadi 16 titik pada tahun 2013. Selain penambahan jumlah titik, terjadi pula penambahan luasan daerah yang tergenang banjir. 


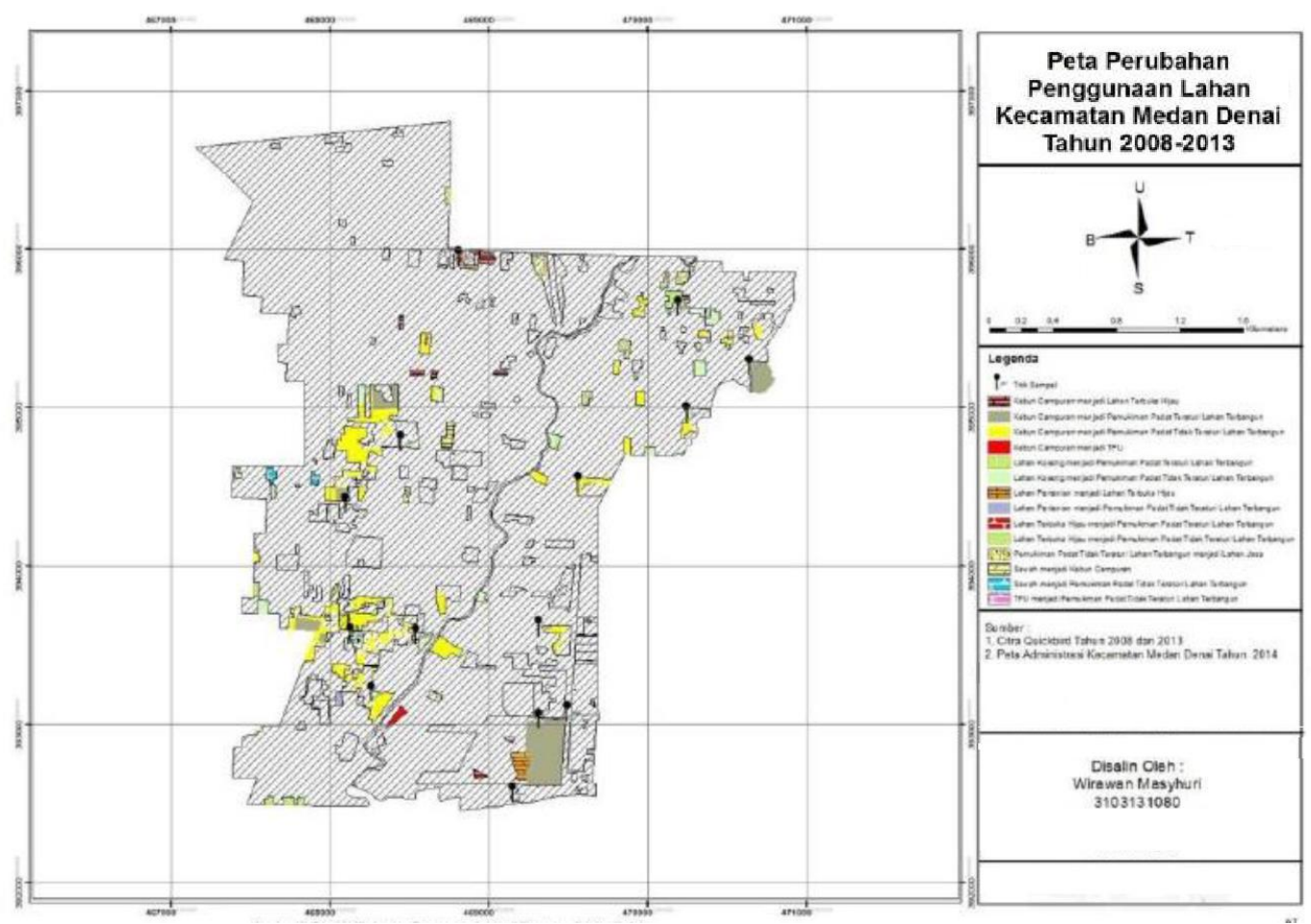

Gambar 1. Peta Perubahan Lahan Kecamatan Medan Denai

Kelurahan Tegal Sari Mandala 3 merupakan yang rentan terkena banjir karena lahan permukiman/ lahan terbangun yang padat cukup mendominasi, jumlah titik genangan/ banjir yang tadinya hanya 3 titik berubah menjadi 4 titik dengan luasan yang bertambah.
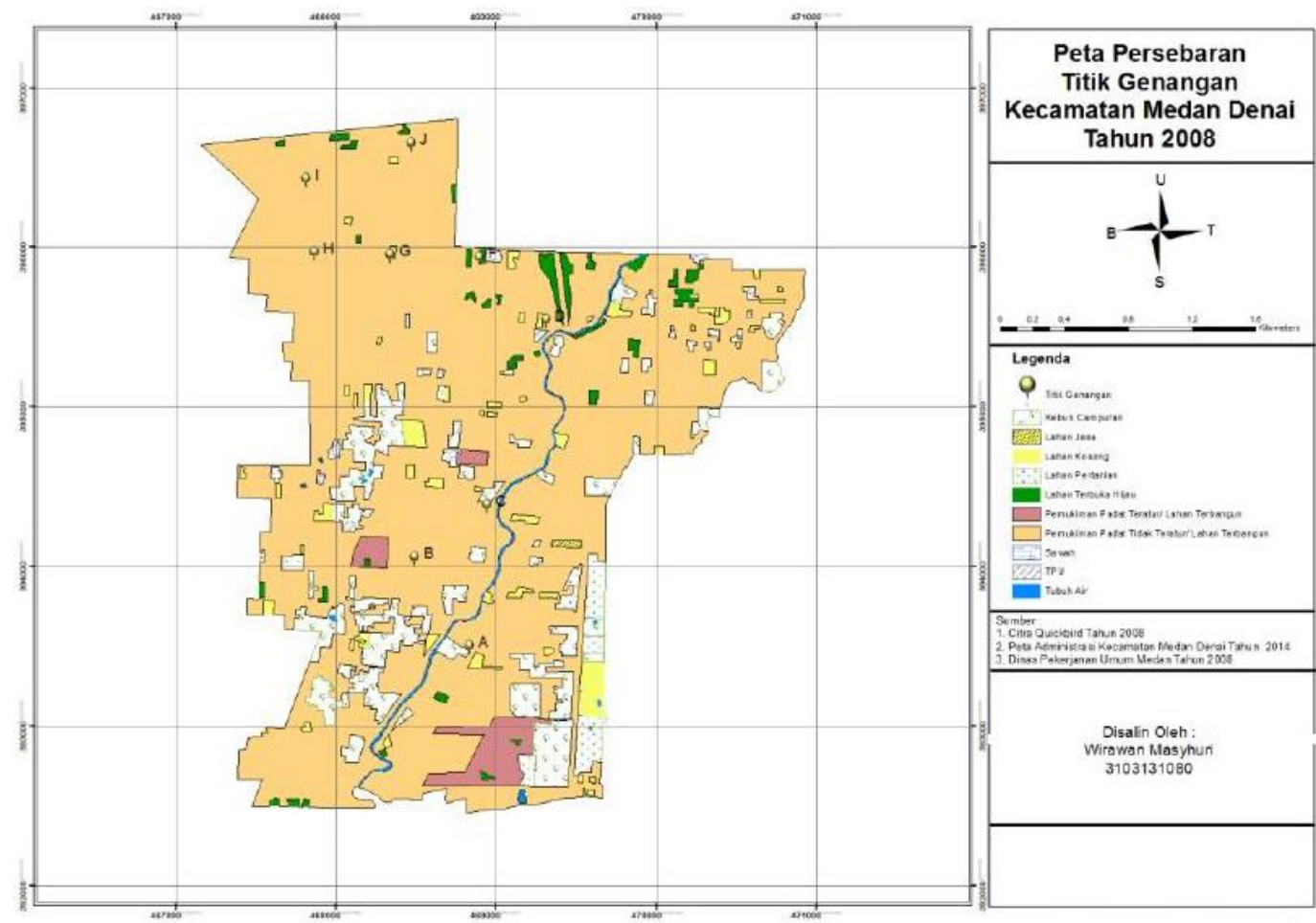
Gambar 2. Peta Sebaran titik Genangan Banjir Medan Denai Tahun 2018

\section{KESIMPULAN DAN SARAN}

Berdasarkan pembahasan adapun kesimpulan yang dapat diambil dari penelitian ini adalah :

1. Penggunaan lahan yang paling banyak mengalami penambahan luas dalam kurun waktu 5 tahun terakhir adalah permukiman/lahan terbangun sebesar 50,41 ha atau $96,55 \%$.

2. Banjir di Kecamatan Medan Denai yang terjadi akibat perubahan penggunaan lahan yang signifikan yang muncul akibat dominasi lahan permukiman/ lahan terbangun

3. Kelurahan Tegal Sari Mandala 3 merupakan yang rentan terkena banjir karena lahan permukiman/ lahan terbangun yang padat cukup mendominasi.

Adapun saran yang dapat diberikan dari hasil penelitian ini adalah:

1. Bagi pemerintah perlu memperhatikan dan meninjau kembali perubahan penggunaan lahan yang terjadi di Kecamatan Medan Denai yang sebagian besar lahannya merupakan lahan terbuka hijau yang mengalami perubahan menjadi permukiman dan penggunaan lainnya, sehingga tentu saja lahan terbuka hijau yang ada akan semakin berkurang dan lama kelamaan akan habis dan akan mengakibatkan banyak bencana alam yang mungkin akan terjadi dan jika tidak diatasi, pada saat itulah orang - orang baru menyadari pentingnya lahan terbuka hijau sebagai daerah resapan air di suatu kawasan, maka dalam hal ini pemerintah harus melakukan penyuluhan dan tindak nyata dalam melestarikan lingkungan hidup, dan membatasi pembangunan perumahan di areal ruang terbuka.

2. Bagi masyarakat perlu adanya pengetahuan yang lebih akan pentingnya lingkungan hidup yang baik, untuk dapat menciptakan kehidupan perkotaan yang indah tanpa harus adanya kemacetan, banjir, dan masalah kota lain.

\section{DAFTAR PUSTAKA}

Anonim. 2007. Kerangka Aksi Hyogo Pengurangan Resiko Bencana 2005. 2015 dalam Membangun Ketahanan
Bangsa dan Komunitas terhadap Bencana. Jakarta : Bakornas PB.

Badan Pusat Statistik (BPS) Kota Medan. 2013. Kecamatan Medan Denai dalam Angka 2013. BPS: Medan

Damanik, M. R. S., \& Restu, R. (2012). Pemetaan Tingkat Risiko Banjir dan Longsor Sumatera Utara Berbasis Sistem Informasi Geografis. JURNAL GEOGRAFI, 4(1), 29-42.

Irianto, G. 2004. Alih fungsi lahan: Dampaknya terhadap Produksi Air DAS dan Banjir. Pusat Penelitian dan Pengembangan Tanah dan Agroklimat. Badan Litbang Pertanian

Karoko, S. A, 2013. Hutan Gundul, Sungai Tertimbun, Medan pun Diterjang Banjir. Mongabay. https://www.mongabay.co.id/2013/10/ 16/hutan-gundul-sungai-tertimbunmedan-pun-diterjang-banjir/ (diakses 12 Februari 2015)

Miles, B. Mathew dan Michael Huberman. 1992. Analisis Data Kualitatif Buku Sumber Tentang Metode-metode Baru. Jakarta: UIP.

Petit C, Scudder T, Lambin E. 2001. Quantifying processes of land-cover change by remote sensing: resettlement and rapid land-cover changes in southeastern Zambia. International Journal Remote Sensing. 22(17): 34353456.

Prahasta, Eddy. 2009. Sistem Informasi geografi Konsep-konsep Dasar. Bandung : Informatika Bandung

Samosir, T. 2011. Karakteristik Ruang Terbuka Hijau pada Kawasan Permukiman di Kecamatan Medan Johor Kota Medan. Skripsi (tidak diterbitkan). Medan: Fakultas IImu Sosial Universitas Negeri Medan.

Sitorus, Santun R.P. 2011. "Kriteria dan Klasifikasi Tingkat Degradasi Lahan di Lahan Kering (Studi Kasus : Lahan Kering di Kabupaten Bogor)". Jurnal llmu Tanah dan Agroklimatologi Vol 8, No 2/Desember 